\title{
4
}

\section{May: Muslim Women Talk Back-A Political Transformation of Secular Modernity on International Workers' Day}

\section{Lena Martinsson}

\subsection{Introduction ${ }^{1}$}

Today, truths are said [cheers], and today, we stand here together, the first of May 2017. It is a historical day, and all of us who have taken part have written history [cheers and clenched fists raised in the sky]. We rewrite history with rights for Muslim women and Muslim women as main figures who write the history of resistance [cheers]. And we demand, as Aftab just said, that the self-appointed feminist and anti-racist government break its long, violent silence and condemn this verdict and stand up for Muslim women's rights to work and to their own identity. (Sabrin Jaja, May 2017)

The quote above is part of a speech given by Sabrin Jaja after a march through central Gothenburg in Sweden on International Workers' Day

\footnotetext{
L. Martinsson $(\bowtie)$

Department of Cultural Sciences, University of Gothenburg,

Gothenburg, Sweden

e-mail: Lena.martinsson@gu.se 
on 1 May 2017. Several hundred Muslim women wearing veils ${ }^{2}$ had filled the streets, marching alongside members of socialist parties and workers' unions. At the same time as the women marched under their banner Don't touch our bodies!, similar demonstrations were taking place in two other big cities in Sweden. ${ }^{3}$ All three marches were organised by highly knowledgeable young women in Muslim civil society. The women addressed the experience of exclusionary processes in the workplace and the gazes, threats and violence that made it dangerous for them to walk on the streets and take part in public events in their everyday lives. They also criticised European governments and nations' long-established exclusion of Muslims and Islam from the history of European modernity (cf. Abu-Lughod 2013; Fanon 1963, 1965). As an ally, I walked at the end of the march.

Starting with the organisers' own analyses and strategies, I want to reexamine this day, the march, artefacts, speeches and actions, to study not only the struggle against a Eurocentric and Swedocentric hegemonic secularism and its colonial history but also the ongoing emergence of communities and collective political subjectivity. I aim to follow the use of time and temporality, how futures and histories were created by the activists along with feelings of belonging and disbelonging. The organisers lived in Sweden and were Swedes, but were continuously questioned and othered. Their political struggle was in-between-as both insiders and outsiders in Swedish society (cf. Spivak 1993). The veil was a paradoxical node in the march and the speeches, so I treat it as such in this chapter. That day the veil connected the demonstrators to each other, worked as a bonding object and marking them out as a strikingly distinct and visual political group. Yet the demonstrators' struggle did not concern the veil but rather the excluding processes to which they as Muslim women were exposed.

The verdict referenced in Jaja's speech is one example of the history of the exclusion of Muslim people in Europe and Sweden. This ruling from the European Union (EU) Court of Justice states, in short, that it is not discriminatory, directly or indirectly, to dismiss a person from her job if she is wearing what the verdict calls a headscarf in the workplace. The headscarf has been an important artefact in European colonial history, 
highlighting notions of what Europe is and what the future of Europe should be (Abu-Lughod 2013; Amer 2014; Fanon 1963, 1965; Scott 2007, 2018). One important trait is that the veil as well as Islam are made into something that does not 'belong' in Europe. On one side it is made into a direct threat against Christianity; on the other hand, and not least in Sweden, Islam and the veil are also constructed as threats to modernity and gender equality. The veil is posed as a contrast to the strong idea that there is only one modernity developed in a secular rationality; the veil is associated with traditionalism, reactionary forces and oppression against women (Asad 2009; Çağatay 2018; Farris 2017; Kundnani 2015). The EU verdict potentially excludes Muslim women in Sweden from not only the European labour market but also what is sometimes understood to be the most modern project of all: the Swedish gender equality regime (Martinsson et al. 2016). Being part of this regime and, therefore, part of society requires gainful employment. The vision of Swedish gender equality is built on the idea that every adult should work, preferably for eight hours a day. Through work, one gains access to parental leave, health insurance, retirement, respectability and recognition. It is an important aspect of the Swedish body politic (de los Reyes 2016; Giritli Nygren et al. 2018).

Since the Swedish government did not react against the verdict hindering Muslim women wearing the veil to work, its silence became, as stated in Jaja's speech, one more violent act of exclusion. Such acts of exclusion create the Muslim women as the others, those who do not count in the EU and Sweden. The others become a we forced in this moment in history, as Jaja points out, to bang on the wall from outside the ongoing production of Swedish secularism and modernity. This we has a long history of exclusion and disbelonging. The march, speeches and themes thus highlight the close connection of the problematic history of time and temporality to the emergence of communities of belonging and communities of disbelonging. In this chapter, therefore, I argue that these demonstrators took part in a possible reconstruction of the history of modernity and the view on secular positions as a prerequisite for democracy. They urged an understanding of religion other than that dominant in nations such as Sweden and thereby stressed the importance of 
rethinking the secular and its 'truth claims, its promise of internal and external goods' (Mahmood 2009: 65).

It becomes quite clear that I understand secularism not merely as a description of a governing system that divides religion from the state but also as a steering discourse itself (Scott 2018). Secularism is often understood as part of modernity and contributes to constructing Europe and Sweden as non-Muslim and non-Jewish and Christianity, as Talal Asad (2009) wrote so clearly, as almost secular and therefore neutral. In line with Rivera (2012) and Mouffe (2018), I do not recognise only one possible modernity or, for that matter, one form of gender equality and democracy. To assert such a universal claim is an expression of power used, not the least, in colonial rhetoric. Modernity and the associated understandings of history and future are a recurrent theme in the material from 1 May 2017 in Gothenburg. This, of course, is not strange; how time is organised and understood is a strong normalising and political force (Edelman 2004; Halberstam 2005; Puar 2007). Dominant understandings of time become part of creating territories and national imagined communities such as Europe and Sweden, we and them (Anderson 2016). Swedish exceptionalism, in particular, is built on an understanding of time as linear, making the world's most modern, developed, gender-equal, secular nation a role model for other countries to follow, the one that has found the way to the future (Martinsson et al. 2016). This narrative links notions of time with notions of nations, people, gender and sexuality. What emerges is an imagined, universalistic, neocolonial future in which some nations lead others. The idea of this rational future constructs realities in the present (Puar 2007), and other communities emerge through these understandings of time, history and futures. The Muslim woman wearing the veil is constantly made into a threat to this linearity. She is rendered the stereotypical other, the non-modern who is understood as oppressed and therefore cannot be listened to. She poses a danger to development (Ahmed 2004). As the other, she is the non-normative, and the stereotypical notion of her is a condition for the norm, the privileged (Butler 2015; Berg et al. 2016; Martinsson et al. 2016; Giritli Nygren et al. 2018; Puar 2007).

At this conjuncture, the veil works as a node for different struggles and existences. As in the case of the future, numerous, different understandings of the veil and its role and agency vary significantly (Amer 2014; 
Abu-Lughod 2013; Lilja and Martinsson 2018). The understandings of the veil merges and transforms in different contexts. But the veil is also performative itself, functioning as a bonding object and thus creating communities that go beyond national borders and specific times. The veil is always part of assemblages; for instance, in this chapter it connects to the different placards, songs, streets, bodies, narratives and discourses discussed in this chapter.

As mentioned, I am interested in the emergences of political subjects, political we. My starting point is not an assumption that there exist given political subjects and communities of belonging or that some political subjects such as class and gender are most important to social change (Laclau and Mouffe 1985). Mohanty (2003) critically wrote about how the western white woman has understood herself as the political subject of transformation for all women. In the 1990s, Judith Butler (1990) warned of the risk of understanding the category of woman as an essential political subject. The category was produced by the discourses at hand, she argued. I argue for an unessential and far from predictable understanding of political subjectivity. Many groups can be formed and recognised as political forces and as allies.

Methodologically, I follow how political subjectivity emerges individually and collectively in specific historical situations and assemblages. It is not possible to know beforehand which groups will be formed and what political impacts different groups will have (Martinsson and Reimers 2016). I am especially interested in this process when communities are shaped, and groups are interpellated by others and by themselves as groups with common interests, as in Jajas speech. To understand I follow how talks, artefacts, bodies, reflections and material conditions such as the pavements, square and right to an income become parts of productive assemblies.

As a scholar from a Christian-secular context, clearly recognisable and interpellated as white and Swede with all the attached privilegies, I find it necessary to share my own position and what it can imply for what sorts of knowledge are achievable from this hegemonic position. I, therefore, use my reflections, first-impression analyses and hopes as material to scrutinise and compare them with the organisers' thoughts and analyses. I am not studying who the organisers are or attempting to represent anyone. Instead, I am interested in the political struggle, subjectivities and transformations and the need for some to start following instead of trying 
to lead oppressively. Accordingly, I have followed the reproduction of Islamophobia in the media and political rhetoric, listened to debate panels and analysed television shows. I have not been a scholar standing outside this struggle. I took part in the march as an ally and later I accepted an invitation to moderate a very questioned conversation in connection to a screening of the film Burka song 2, which some of the organisers had arranged. As a member of the board of Antirasistiska Akademin (AntiRacist Academy), I came to know and subsequently interview the march organiser Maimuna Abdullahi. She was a central figure on the march and she became crucially important for this text. I took many pictures during the course of the march and later used five of these photos as a basis for sharing my reflections with Abdullahi. I analysed the slogans and speeches called out during and after the march. Abdullahi described the Muslim women who walked in the march while wearing the veil as those 'who own the march', so I have called this group the owners.

\subsection{The Verdict}

As mentioned earlier, the march was organised to protest against an EU court verdict ruling that it is not an act of discrimination for businesses to prohibit women from wearing headscarves when they hold official, representative positions in their workplaces such as receptionists:

The court therefore concludes that the prohibition on wearing an Islamic headscarf that arises from an internal rule of a private undertaking prohibiting the visible wearing of any political, philosophical or religious sign in the workplace, does not constitute direct discrimination based on religion or belief within the meaning of the directive.

By contrast, such a prohibition may constitute indirect discrimination if it is established that the apparently neutral obligation it imposes results, in fact, in persons adhering to a particular religion or belief being put at a particular disadvantage. However, such indirect discrimination may be objectively justified by a legitimate aim, such as the pursuit by the employer in its relations with its customers of a policy of political, philosophical and religious neutrality, provided that the means of achieving that aim are appropriate and necessary. It is for the Belgian Court of Cassation to check those conditions. (Court of Justice 2017) 
The verdict legitimises indirect discrimination that has an 'objectively justified aim such as the pursuit by the employer'. Companies' supposed needs, which could arise from racist notions among customers, are evaluated as more important than rights such as gender equality and freedom of religion. The interests of capitalism, represented in the verdict, are placed first, and the rights of these women are only secondary. The capitalist ideology as an organising materiality is understood to be neutral, but wearing a hijab, veil or headscarf is not. This secular discourse allows no room for religious signs in public but freely gives it to capitalism (Asad 2009).

The veil has long been an artefact of struggle between the colonisers and the colonised, as Frantz Fanon (1965) had shown in 'Algeria Unveiled'. Veiling, as Sahar Amer (2014) emphasised, has been in the middle of a range of complex historical processes. The verdict, therefore, should be analysed as a reiterative act of colonial and historical violence. The march organisers and I understand the verdict's demand for neutrality from a postcolonial perspective as a means of reproducing the colonial order inside Europe. Again, Europe is articulated as different, in the forefront, more modern, secular and democratic. To continue to exclude Muslims and Jews is to recreate the idea of Europe as white, Christian and secular. The verdict and the establishment of what is understood as neutrality excludes the others from the imagined European community. A political construction violently pushes aside other possibilities (Mouffe 2013). The colonial history making Muslims into non-neutral, nonEuropeans is raised again. Abdullahi discussed this issue at length in the interview:

But I think we want to convey the message that neutrality is not something to wish for [...] if [we] think that where there is a principle of neutrality, there will also be human beings that fall outside, and some will be on the inside. Who are these people? And historically, even if you are not talking about neutrality, there have always been people who are let into a community of belonging and people who have to stay on the outside. And in the Islamophobic history of Europe, it has been the way through which the task of civilisation has been legitimised. Some can join, and others are not with us because they are not like we are. That is why it is so cynical in 2018 to talk about principles of neutrality. 
In understanding the verdict, Europe's history of inclusion and exclusion is particularly significant. Abdullahi told me about the situation in Andalucía in 1495 when Muslim groups were driven out by Christian forces after a 700-year-long period of Muslim high culture. She continued:

With the nation-state, there are some people who get a place, who are included, and it is not Jews, and it is not Muslims. They can't get evangelised. They don't have pure blood-we are not talking biological. We are talking about that they don't even have the right values; we must control what they eat, what clothes they have. These debates have been going on, and they have had enormous consequences. And when these debates are up, the next question is 'What do we do with this people who are not supposed to be here but are obstinate and are here anyway? We have to find a solution for it'.

Abdullahi laughed and continued to emphasise that the question of socalled neutrality is a very important one: 'it has a history'. She continues to ironically state that 'it is just a single case [...]. No one is racist. The court is also neutral. Everyone is equal before the law.'

Abdullahi and the other participants in the march recognised the verdict as a historical reiteration of Islamophobia in Europe. The assumed outside of neutrality, modernity is a history of never-ending exclusions. Whereas those invited into the modern community of secularism are presumed to identify with the bright future believed to be coming, the excluded have a future of new exclusions. In the interview, Abdullahi positioned herself and the other march participants as political subjects in this never-ending, reiterative process of exclusions. They are here for a while, taking part in a struggle they assume succeeding generations will need to continue:

We are merely one in the line of several generations who have contributed to putting us where we are today, but what we can do anyway is to leave an impression, a footnote in the history to our children and grandchildren and their children-if we still have this planet by then-to look back and see 'how the Muslims had it'. Because I think the situation will be worse, so that there at least exists some sort of documentation that there was actually a resistance; people didn't give up. And that is the least we can do today. So even if it is symbolic actions, they become very important for the writing of history. 
The future is non-existent. It will not be better. Abdullahi's analysis connects the activists into a long chain that extends beyond themselves. The historical dimension carries a reminder that there always has been resistance, and it will continue with the next generations in even harder futures. Future generations need to know that they who live now have tried. This historical analysis constructs a community of belonging stretching over time, what has been and what will be-the past and the future. As Muslims are excluded from the dominant order, they create a political we comprised of those who have gone, those now living and those who are still to come — an imagined historical political community of resistance and religion but without a nation and without much hope. Through the march and other struggles, they become placed in a historical context, and the owners became both smaller as a footnote in the history and bigger as part of a long history.

It is noteworthy to compare this understanding of the future with that of the Swedish gender equality model. With the Swedish model follows a linear development. Here, the imagined community becomes the modern we, the forerunners. A future full of hope awaits those on the inside. The others who are excluded should adhere to or assimilate with this Swedish model. The descriptions of history are very different, but the Swedish gender-equal, modernistic, secular version is double-edged and performs nationalistic and exclusionary functions. The march owners saw that they had been abandoned by a government that had not pushed against the verdict but, instead, as Jaja stated, was violently silent about it. The march owners were thereby excluded from the gender equality model and not recognised as workers (see Butler 2015: 25).

\subsection{The Demonstration}

The march owners experienced the historical reiteration of Eurocentric Islamophobia on their own bodies in their own suburbs and through images of themselves. In the media, politics and business, the veil has been a node for different forms of struggles and stereotypical imaginations. Muslim women wearing the veil have been threatened and abused, exposed to gazes, hate and notions of exclusion (Amer 2014; Berg et al. 
2016; Lilja and Martinsson 2018). Like Abdullahi, Jaja had been deeply involved in political and social movements where she lived. In an interview conducted by the Antiracist Academia (2019), she explained that she and the other activists in the suburb had acted against the notions behind various integration projects and felt that the ordinary political parties that some of them had joined had not acknowledged their experiences. Jaja and Abdullahi addressed the importance of not only responding to problematic attacks and oppression. As a collective, they needed also to take time to reflect, studying, analysing, gaining knowledge, raising consciousness levels, verbalising situations and, as Jaja stated, 'understanding that the oppression you feel is there'. Together they studied academic theorists such as Frantz Fanon, Edward Said and Paulo Freire. Jaja pointed to the need for a new political we, beyond the left and anti-racism:

Directly, when you thought about antiracism and resistance, the first thing that came in your mind was 'the left'. We tried all the time to put our self in a sort of left pattern.

Quite quickly, it became clear that it wasn't the place for us to struggle from. We could identify us with the workers' movement to a certain extent but not totally. We had one more dimension, and that was that we were racialised. The working class is very coloured today. We were very lost about this. What sort of struggle are we in? So, when we found these theories Fanon, Said, Freire, it was so strengthening and relieving just to study this stuff. (Interview, Antirasistiska Akademin 2019)

The quote is one of many examples in the material of being simultaneously part of, and detached from, something. In this case it is the leftist movement that had created this ambivalence. This experience, together with their new knowledge, was decisive in the emergence of a new political subjectivity. Both Abdullahi and Jaja had stressed the need to go into the community of activists of which they were a part, to conduct analyses and figure out the community's own path. Yet Abdullahi always prepared to also connect to others. By the time I met up with her for an interview some time after the demonstration, both Abdullahi and her friend Fatima Doubakil had been labelled extremists by the city's Social Democratic mayor. They were no longer allowed to use rooms owned by the 
municipality for their meetings; they had become persona non grata. The situation was a tense one, and they had become very exposed in the media. Abdullahi, who soon after would get a master's degree in social work, shook her head and observed: 'We will never get a job in this municipality.' During the same period, some colleagues and I had been criticised for organising a seminar on whiteness studies and gender studies, and both neoconservative and anti-gender movements had attacked our research. Abdullahi recalled what had happened to us in academia and connected it to the struggle in which they were engaged. Her analysis was that the attacks were against different forms of knowledge production. We had become allies, for a moment exposed to and struggling against the same forces, a we. She laughed at the tumult she and Doubakil seemed to have caused: 'We just want to sort of talk about post-colonialism and arrange study circles.'

In this instance it was knowledge production that had made activism possible. The EU verdict was expected, the organisers waited for it to come, and they were prepared to do something about it. When it arrived in March 2017, the analysis and mobilisation were in place.

\subsection{About the Assemblies in the March: Five Pictures}

I was told that many of the participants in the march had never before taken part in such a demonstration. Indeed, many had never even set foot in the inner city. These areas had not been open to them.

Participating in the march was also an affective moment for me. At the start of the march, I had no intention of writing about it. I was simply there to support the struggle. Halfway through the march, I changed my mind. What I saw, felt and experienced was something quite new to me, and while walking in the march, I analysed it as a decolonial political practice, resistance and possibilities for transformation. The many bodies, voices and placards became significant. I recognised how the organisers worked strategically with connections and perhaps interventions in some organisations such as the workers' and the women's movements. I felt hope and courage. 
After my meeting with Abdullahi, I had reflected on my experience and feelings and saw that they were correct but very superficial. Abdullahi had a quite different perspective, which became clear when we discussed why they had walked with the syndicalist movement. When I attended the 1 May demonstration that year, most was business as usual. Numerous parties, organisations and unions marched from different parts of the city to many meeting points in the city centre, where speeches were given throughout the day. As in every year, the syndicalist procession started from Masthugg's Square. Usually, the group in this section was quite small, but on this day, it was swollen by many hundreds of women in the veil and their allies. The Syndicalists in Gothenburg had declared that solidarity was necessary to hinder competition among workers, so they identified themselves as a feminist and anti-racist organisation. However, this was not the reason why Abdullahi and the other organisers had chosen them. Instead, as Abdullahi explained, it was the Syndicalists' experience and knowledge of state-sanctioned violence and oppression. Another argument was that the Syndicalists would not panic if identified as extremists in the media. I compared Abdullahi's answer with my own interpretation that the owners had built an alliance with the workers' movement to make the question of the verdict into a workers' rights issue. That analysis was not incorrect, but it did not explain why the owners had chosen a marginal party rather than the Social Democrats or the leftist party Vänstern.

Our answers highlighted our different lives and relationships to the state and media. The owners wanted an organisation with similar experiences to their own as they knew that the state was not a supportive force but a threat, and the media was not a friend that would spread the news but a force that could create panic. However, I was right with regard to the idea of political communities merging with each other. The demonstration made the question of the veil into a question of workers' rights. As workers, the women needed the same rights as anyone else. This demand clarified the strategy for the day. The owners refused to be excluded and would take their place together with other workers. They stood up to resist the dominant order that counted them neither as workers nor as part of the welfare society. 
Another important but simplified reading of the situation concerned how I understood the many bodies assembled in the streets. During the march, I was thrilled by the strong symbolic meaning of all these women with veils filling the streets with their bodies, minds, experiences and, not least, their voices. I connected it to the queer nation's slogan: 'We are here. We are queer. Get used to it.' Refusing their exclusion, they took possession of the streets. While I had seen the march and valued it as a brilliant strategy, Abdullahi made it more complex when she told me about it. The context of the march was also the fact that as individuals the march owners could not walk through the city without hateful gazes and even attacks. She recalled the everyday experience of being excluded as different which she had shared with many others. While planning for the march, they had carefully discussed what would happen if they together, as a collective, went through the city. How provocative would it be? It was not merely a discussion about politics but a question of safety; by their actions they had put themselves at risk.

The differences in our analyses of what it meant to walk through the city again demonstrated our different positions: my privileged position looking for visions and hopes for new connections for the group participating and Abdullahi's and the owners' need to consider questions of safety and their clear, everyday experience of coloniality as an active marginalising force that hindered them from taking part in ordinary city life. To appear on the streets had a cost, indicating how places remained white, cleared of all religious (apart from Christian) expressions. While I saw how the march challenged stereotypical notions of those women in the veil, Abdullahi was prepared for attacks and gazes. She said: 'We don't go here and march for the sake of marching. It can cost us something too.' Abdullahi told me that they had discussed walking in the neighbourhoods where they lived, but they had argued that for them the EU verdict was not an issue solely for them. Instead, they wanted to go out into another forum and take a place in public that should be theirs. The squares and the bodies in the march were far from their usual places. When watching the march, it was important to understand these many senses of nonbelonging that Abdullahi said were challenged - at risk.

In Notes towards a performative theory of assembly, Judith Butler (2015) wrote about the constructions of the people and the constitutive outside, 
or those who are excluded as not belonging to this people and thereby indicate where the 'borders' are. There is no inside without this outside; the not-normal is the condition for normality. I came to understand that the group in the march was part of this constitutive outside. In the march, this group claimed the streets. Together and very visibly, they performed an intervention and thereby refused to be the constitutive outside on which the inside depended (Butler 2015).

I took many photos during the march and I discussed five of them with Abdullahi. The first photo we looked at was taken just before the start of the march. It showed the first line of participants. Their many placards were in different languages and connected to various political discourses. Abdullahi and I studied the picture together, and she pointed to a placard: 'This is in Somali "Farta naga qaad'. It means', she translated, 'don't touch me. Farta means finger, so it also means "Don't point".' It was about, explained Abdullahi, the politics pointing out and accusing people. It had a double meaning. Abdullahi continued to the next sign, 'Who is neutral?', a question, of course, related to the verdict discussed. At that moment, though, I became aware of what happened when the question 'Who is neutral?' was detached from its former context of the verdict and placed in the very visible march by hundreds of women wearing an article of clothing repeatedly made into an object of hate and abjection. The question 'Who is neutral?' became a question beyond the verdict. The materiality, public place and texts worked together as a discursive materiality.

Abdullahi next pointed with her finger to a placard held by a woman demanding 'the right to our bodies'. This was a demand that was repeated by many of the placards, which gave the message in a variety of languages. Abdullahi stressed that this sign was pragmatic. Many women recognise the message and thereby it became possible to identify with the demonstrators. It was also possible to read these placards as an intervention into a transnational hegemonic white and secular women's movement. It posed the challenging question: Who should be counted as women with rights?

Abdullahi (MA) and I (LM) continued to discuss signs about work:

LM: 'Muslim women's right to work' and 'The right to our bodies'. They are a little similar, I think.

$M A$ : Yes, exactly, the Muslim woman's right to work. We discussed this a lot. We March on 1 May. It is the verdict that is connected to work. 
Abdullahi rhetorically asked if any other group of women in Europe could have been so exposed as they had been to laws threatening women's economic independence.

A Europe that thinks they are the best and the most enlightened and struggles for women's rights [...] No one asks what is going to happen now? How are these people going to earn one's living now? On one hand, they deprecate, 'They don't work'. Then they close the door that would have made it possible to work. The racism has a logic, and we will not discuss the veil here.

From Abdullahi's analysis followed the obvious question: Who was Swedish gender equality for? Who was allowed to be part of this gender-equal community or the welfare system? Who could be recognised as modern and independent? The owners addressed rights central to European and Swedish self-understanding. They positioned themselves in this context to show how they were excluded and not allowed to belong. However, this position of disbelonging became - not the least on this particular day-a making of a political we, banging on the wall of the inside. With all their experiences of exclusions over generations, the march owners assembled on the streets, stating that 'they [we]re still here', 'they persist[ed]', and they were 'not disposable' but demanded the right to appear and be recognised (Butler 2015: 25ff). By doing so, they also challenged the idea that secularism was a condition for gender equality, they challenged the notion that there was only one way to go. They questioned the structural connection between gender equality and being positioned as white.

\section{5 'Siblings, Friends, Comrades, Allies, Look What Happens when We Come Together'4}

Abdullahi smiled when she saw the picture of a young woman with a megaphone. 'It is fine', she stated. The organisers had hoped and planned for a democratic march in which it would be possible for many to call out and take leading roles. The demonstrators had three megaphones- at the beginning, middle and end of the march — and passed them from 
hand to hand. This picture and practice challenged notions of the oppressed Muslim woman in need of help (Abu-Lughod 2013). The voices on the march were strong ones, and the echoes among the buildings increased their effects. Two times after each other, they called out (Fig. 4.1):

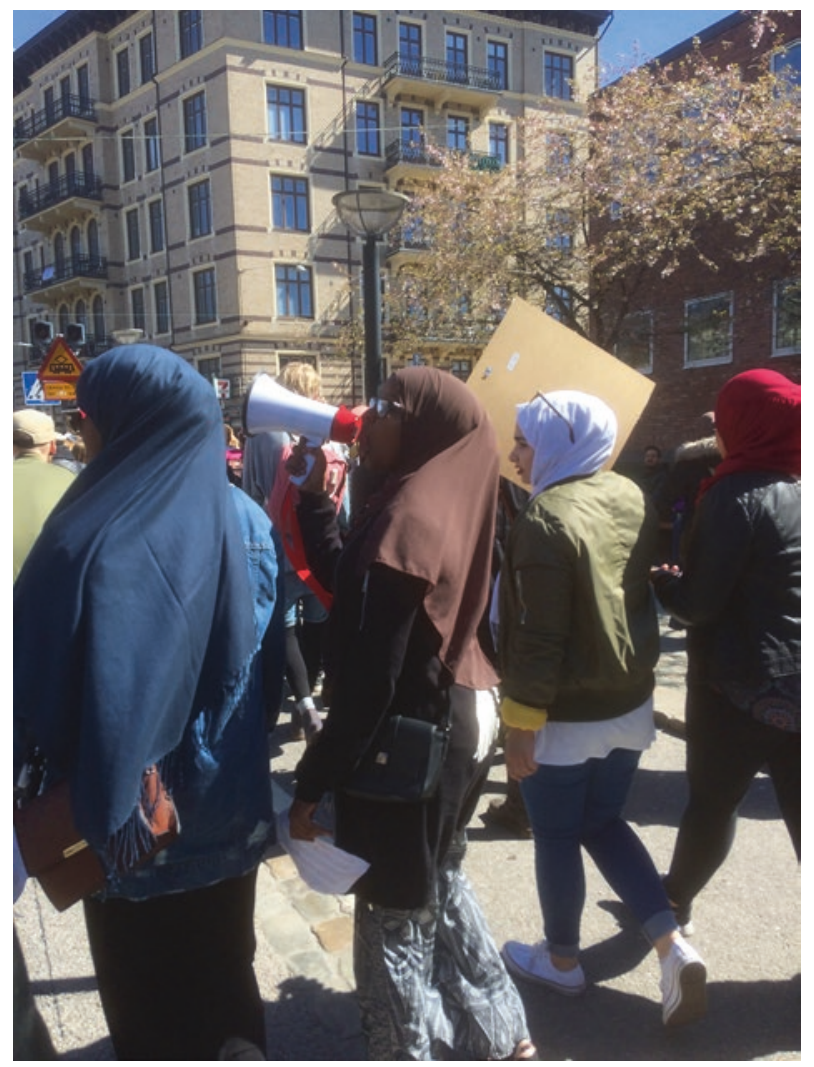

Fig. 4.1 Young woman with a megaphone 
Eh, we will fight.

Eh, we will fight.

Eh, we will fight

'Cause we're strong together, and we'll take our rights. (twice)

Resistance is our hope (hopp).

The right to our body (kropp).

Work is our right,

And together, we create solidarity. ${ }^{5}$ (twice)

The megaphone was a political apparatus that made it possible for hundreds to raise their voices together in interpellation and, not the least, act as a group, aware of each other's bodily existence (Butler 2015). It may also be stated that this calling out was a materialisation of a collective political subject. The voices interpellated us, the others, to recognise this collective political subject. The lyrics also carried the meaning that the demonstrators should talk to themselves and should act, fighting, resisting and creating solidarity. They made it clear to the world that they existed as a political subject with the right to be in this space. The veils, megaphones, owners, streets, songs and lyrics called out became an assembly that worked deconstructively, tearing apart stereotypical notions of women in the veil as silenced, and simultaneously stressing the importance of the ongoing emergence of a political collective.

\subsection{The Last Shall Be First, and the First Last}

We who were called the allies, who had that in common that we didn't wear the veil but were supportive to the struggle, were welcome to walk with the owners in the march. We walked behind them at the end of the march. I asked Abdullahi why they let us come with them? (Fig. 4.2)

Yes, I will be totally honest. I don't totally remember. But [...] it was not a separatist demonstration. We were very clear about that; it was $1 \mathrm{May!} \mathrm{OK}$, and the focus should be that it is Muslim women above all who are in the front, not because of visibility, but because this is their question. It is our question, and it is we who should own it. Then it is open to all, everyone 


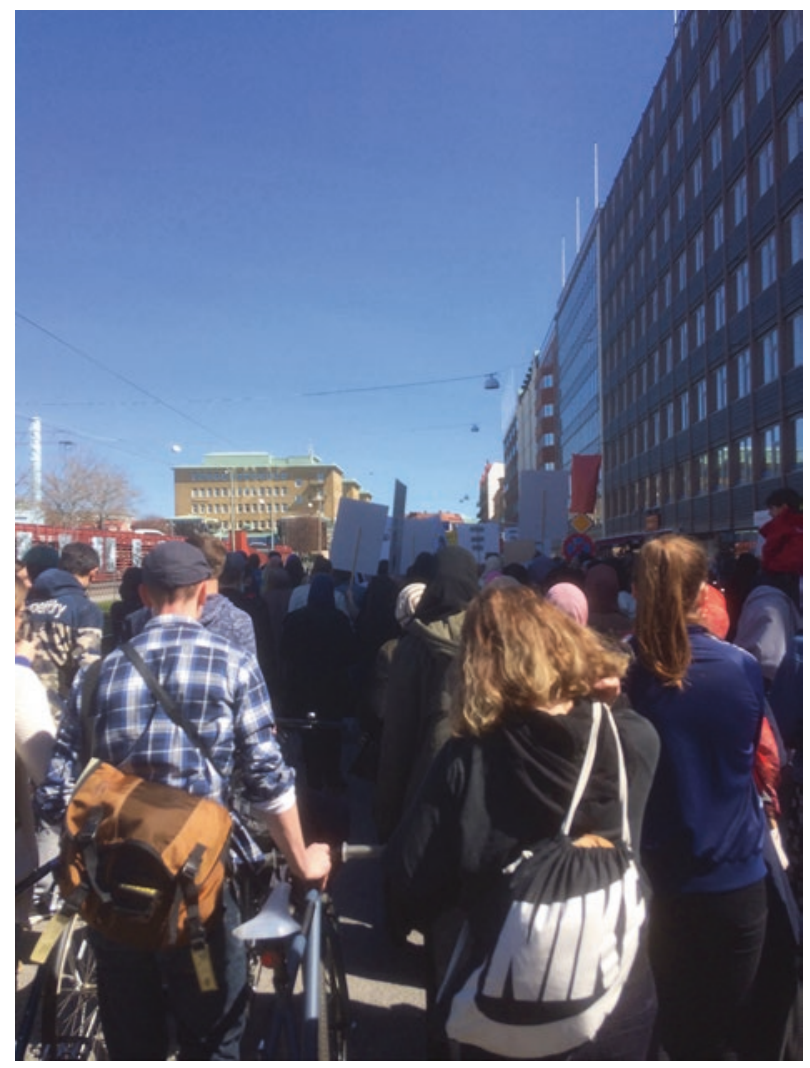

Fig. 4.2 The allies come last

who wants to contribute [...]. Also this, to perceive that we have many persons around us, with whom we both work and cooperate and who we have in our everyday life, who in different ways identify themselves as antiracist and who are anti-racists. And here, you have a possibility to join in something you will not necessarily get cred for, but it is the principle that you are with. [I] think it was something like that.

Many of us who came behind in the march were positioned as white, and due to this identified as Swedes, part of an imagined community recognised by many as gender equal and a role model for the rest of the world to follow. Now, in this very symbolic march, we, the privileged allies, 
followed the lead of the demonstration owners (cf. Anzaldúa 1999). Drawing on Fanon's reference that 'The last shall be first, and the first last' (Fanon 1963), we were not the role model. The decolonial struggle had removed us from our imagined leading role. The strugglers, the march owners, were now first, the political subjects opening new understandings and futures.

Many who followed could be described as another kind of connecting community. Their engagement and support emerged from sharing everyday life with the organisers. Abdullahi reiterated the collective work on the march. Not the least, she talked about the people with whom they shared 'everyday life'. In particular, the feminist Women's folk high school [kvinnofolkhögskolan] located in the centre of Gothenburg, and attended by adult women with persons that identify themselves as non-binary or with transgender experiences, persons of different ages, speaking different languages, with various backgrounds, goals and study habits. This school became a place for the organisers to plan the demonstration, materialise their message and form a broad we including both women wearing the veil and others. Together, they had discussions, painted signs, made placards and wrote songs. Some teachers also played very active roles, becoming important collaborators and supporters. The work thus influenced the school, and the preparatory work for the march became important to the ongoing emergence of a wider political community of belonging, a community enabled through the joint work. Abdullahi explained:

There were a lot of students who came from the school (Kvinnofolhögskolan) who took part in the march, and that had to do with the fact that we sort of [Abdullahi laughs] lived at the school the last two weeks before the march. We were there all the time, and it was the students who helped us translate into Arabic and Somali, who asked what we were doing when we carried around a lot of stuff. We said that we were organising a demonstration and asked them to spread the word. And then it is like this: a lot of people share each other's everyday lives, and when you do that, you become close in another way. And then the women who wear veils at school-I don't know what they said to their classmates, but I suppose that it had to be something in line with that we are going to have a demonstration against 
something that is threatening our existence. Come! And then people came, and it has to do with that people are classmates. Everyone can come.

The school could be described as a pluralistic, unchosen cohabitation that made possible far from predictable political alliances. The classmates became a new possible community that went beyond but did not dissolve from where the students came. No one asked the other students to identify with their positions, but all were welcome to take part in a struggle important to some of them (cf. Larsson 2010). To a certain extent, this co-work and cohabitation also pointed to another future directed not at the question of being included in something but at the everyday work of transversal border crossing, of the new, possible we, coming from different communities (Larsson 2010). Again, the many different 'wes' were in constant making (Butler 2015: 123). Abdullahi saw this extended we, but also emphasised that the number of people was not essential. Everyone could come, but it was not necessary that they did. Abdullahi, the other organisers and owners of the demonstration were not dependent on it:

We had said that the demonstration, to get people out demands such mobilisation. We had said that and that we, the point is not, we are not after quantity. We are after the symbolic in that we actually do resistance. Whether we are three or five hundred doesn't matter actually. It doesn't take away the worth of what we stand for.

I recalled the historical we, the long chain of historical political subjects doing resistance yesterday, today and tomorrow that was as important as the pluralistic we of today. The two 'wes' did not erase each other. What Abdullahi expressed, I think, was that the extended community was not necessary; another bigger, historical community was more important.

\section{7 'Taking Back One's Dignity'}

The march ended at Bältespännarparken. Jaja went up on stage with Abdullahi and a third organiser, Aftab Soltani. Abdullahi remembered this moment very well. Her mother was there. Even though her mother 


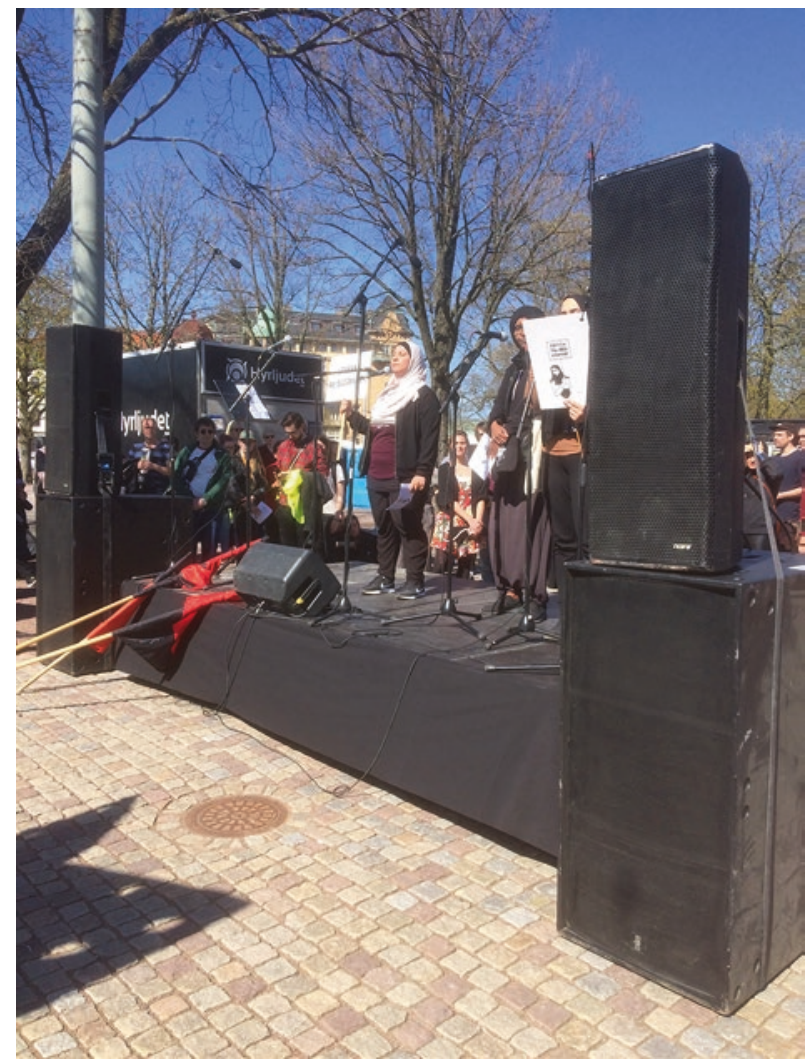

Fig. 4.3 The speeches

worked in social activities, she did not usually take part in demonstrations; this time, however, she had joined and brought her friends. 'Yes, you know, it just spread and spread', Abdullahi explained. She continued to tell about the strong feelings she had while standing there in front of them: 'You know, ladies who have seen you growing up-to stand before them and speak, it was so much emotions.' She repeated that the movement had a historical meaning, and participation was important, but it also had collective importance: 'taking back one's dignity' (Fig. 4.3).

You see how the collective is demonised in relation to mostly black and brown people. It is something negative [...] We are ... not barbaric but not 
developed. We are not modern in that we haven't understood the place and strength of the individual. But, for us, the collective means so much, the collective who has organised liberation movements. It is the collective we have grown up in. It is the collective we have become who we are in, and they try to demonise that which has given us an identity. And here, it becomes one more aspect. I choose to stand here with people whom I see myself in, and there is a radical thought that I recognise these people as important for me [...]. The propaganda says the collective is bad, but we walk together as a collective. It is an active form of resistance, which also will be demonised.

Within Abdullahi's words, the collective who, with their bodies, had appeared in both the streets and history demanded the right to appear and to exist as a collective. A political history followed this collective. When Abdullahi recalled what she felt in Bältesspännarparken, it again became clear that the purpose of the march was so much more than to be recognised by others. It was also to be visible to each other and to recognise the power of the collective. The many bodies, women and sisters were there together. They assembled during a time of demonisation and individualisation and recognised themselves as a collective with importance and dignity. They were not only the others, in relation to a dominant social order that violently excluded them. They were also a we, a visible assembly. The struggle made them into a political subject (Fanon 1963). However, the demonstration was also, of course a moment of talking back. The owners of the march refused to acknowledge Christianity and secularism as modern and democratic in contrast to Islam (Asad 2009). They questioned the idea of neutral, democratic modernity that wanted to transform and civilise Muslim groups. Like Fanon (1963), they pointed to the necessity of societal transformation. Abdullahi's speech contrasted the assumed neutrality to the capitalist labour market and its exploitation of workers' and children's bodies. She rhetorically asked: 'Can you who walk around in your neo-capitalist clothes made by children be neutral?' (Asad 2009). In her speech, Soltani stated: 'The verdict of the EU is nothing else than racist and represents the rights of the company instead of the people.' This analysis made 'the people' a category that one could be part of and align with against EU politics and 
companies. It also stated that the verdict was nothing other than neocolonialism and a victory for the criminalisation of Muslim women who wore the veil. The three speakers connected their speeches to traditional feminism and gender equality, asserting that they had rights to control their bodies, earn their own money, dress as they wanted and be individuals. Of course, instead of merely referring to the nation, they also referred to a transnational colonial history. They pointed out alternative political positions and entry points such as articulating the critique of capitalism in combination with a critique of neutrality and support of the right to wear the veil.

\subsection{The Interpellation to the Steering Party: An Intervention}

When the demonstration and speeches in Bältespännarparken had finished, many of us stayed around, buying ice creams, laughing and enjoying the atmosphere, while some others drifted away. After a while, some of us gathered again. Five hundred metres from us in the largest, most famous square, Götaplatsen, Sweden's governing party at this time, the Social Democrats, were holding their big 1 May rally. The march organisers and owners still present thought we should go there to see if there was a possibility of performing an intervention. The party had been violently silent about the verdict, as Jaja had stated in her speech a half an hour earlier. The owners decided to go to Götaplatsen, bringing the placards and banderols, and some of us allies continued to follow. A government minister and a trade union leader were talking on the stage in the big square. The allies were told to stay in the background. We were given a task to do, but I cannot remember what it was, though I do recall that our role was not to protect the march owners. They, we were told, did not need any protection (Abu-Lughod 2013). The owners rolled up the banderols and went straight into the assembly of people. They became very visible with their placards, veils and hijabs but did not say a word or interrupt. They simply stood silently among the many Social Democratsbodies that assembled and wanted action from the governing party (Fig. 4.4). 


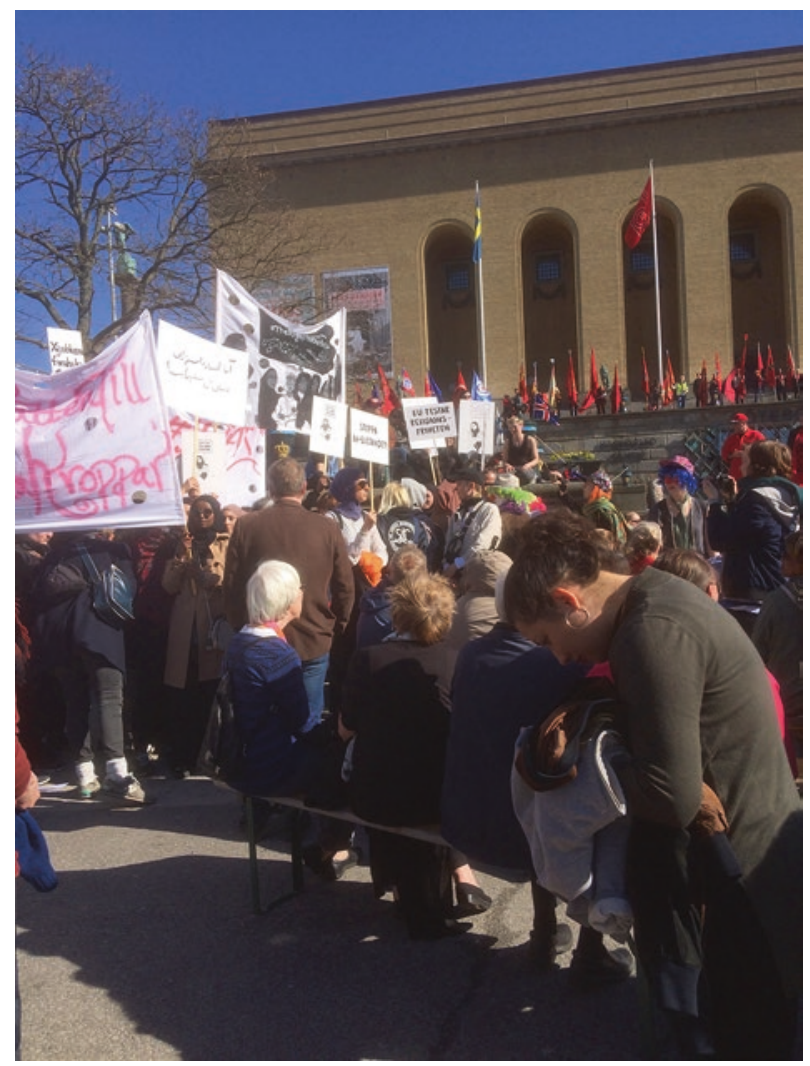

Fig. 4.4 Intervention in to the Social Democratic party's meeting at Götaplatsen

I took pictures with my phone, and when Abdullahi and I looked at them several months later, she tried hard to remember the details of what had happened. She recalled that she had felt a bit embarrassed standing there in silence. I remembered that I had been quite affected by this very performative intervention into a hegemonic social order normalised to act and dress in certain ways. I had understood it as an interpellation to the governing party to act and recognise also these women. Through their political act, they raised a number of questions: Who counted as workers in the Swedish workers' movement? Which women should receive possibilities for gender equality? Who counted as Swedes for whose rights the 
government should struggle? Who were actually recognised as political subjects? Perhaps most of all, it became clear that society could be different, it could already have been different, and it may be different.

At that affective moment, what we did not know was that during the next year and a half, Abdullahi and her friend Doubakil would be defined as extremists by the chief magistrate of Gothenburg, the Social Democrat Ann-Sofie Hermansson. We did not know that Abdullahi and Doubakil would be hindered from speaking at meetings and prevented from using any room owned by the municipality. We did not know then that many forces, from the ultra right to the Social Democrats, would demonise them and do their best to silence them. We did not know the future, but we could see the risk.

\subsection{Conclusion}

In this chapter, I have argued that the Swedish modernity project place a strong value on the idea of secularism. However, while secularism and Christianity become inseparable and part of the imagined Swedish community, Islam and Judaism are excluded from the Swedish and European centre. This exclusion is part of a long historical process. The verdict discussed in this chapter that sparked the idea of a 1 May demonstration is one example of this process and the ways in which Muslim women wearing the veil are not counted in the modernist work of gender equality in Europe and Sweden. This contemporary example is especially serious in Sweden, where gender equality is understood as a national quality, an important trait in the hegemonic, national imagined community. This version of modernity offers a bright future for the hegemonic centre and requires others to adhere, assimilate and stop holding certain beliefs and wearing certain clothes. However, when hundreds of Muslim women wearing the veil acted against this ongoing process of exclusions in the demonstration on 1 May 2017, they challenged the notions that modernity and Swedish gender equality must, by definition, be secular. They also questioned the Swedish self-understanding as a tolerant and democratic nation, of a we and the others. The march organisers and owners performed a decolonial alternative to the story of Swedish anti-religious 
modernity and showed that modernity, democracy and gender equality can be developed and transformed in other ways. This intervention and similar ones challenge the notion of the genuineness of Swedish modernity and gender equality and question at a more general level what modernity and gender equality are and could be.

In varied political situations, different political subjects emerge, and it is far from given that, as predicted by Marxist tradition, these subjects will be the working class (Laclau and Mouffe 1985). Instead, different political subjects with transformational possibilities emerge in different societal and political situations. Following the march and listening to the intellectual societal analysis so important for this movement's possibility to emerge, it is possible to discern numerous different, significant 'wes' or communities of belonging, all of which are important in one way or another to the emergence of the collective political subject that became so clear on 1 May 2017. As Abdullahi, Jaja and Soltani's analysis showed, there was a we beyond the present, a we extending to those who had experienced and resisted processes of exclusion for centuries, and alliances with Muslims not yet even born. Even though it was possible to note that the veil was a transnational bonding object, making visible possible transnational, pluralistic imagined communities of belonging, it was the we constructed over time that became increasingly obvious in the speeches and analyses made by the organisers. The nation, Sweden and even Europe were not, never had been and would not be the limit, and so neither would the present. A second example of communities of importance this day was the national community expressed in the three similar marches in different cities in Sweden. A third community obvious on this day was the local community in Gothenburg, built on sharing everyday life in the suburbs, doing political interventions over a long time, knowing each other's families and sharing experiences of exclusion by the municipality and the state. Another group also worth mentioning emerged between the owners and their allies. The different communities of belonging and the collective political subject emerged and became visible through the struggle, and as the owners of the march and the movement emerged as political subjects, the notion of the centre became less stable and even transformed (Fanon 1963). 
The analyses of Abdullahi, Jaja, Soltani and the other organisers were made from the outside of Swedish society, and it was also from that position that this special, political we has emerged historically, in the present and in the imagined future. Their analyses have exposed the unrighteousness of the situation and the violent making of modernity and gender equality as belonging to only a few, a process demanding total assimilation into a Christian-secular understanding of society in which others' clothes become dangerous, others' beliefs are threatening, and others should be civilised, as Abdullahi stated. At the same time, such assimilation always seems to be out of reach. To be excluded over and over again while simultaneously being a political subject on the outside has impacts on the possibilities for creating an image of a future for the community and political struggles. Processes of exclusion and resistance also mark the future. Meanwhile, the forward-looking, linear discourse on a secular modernity and secular Swedish gender equality embraces others, creating the privileged, like me, who seem to move on into a supposedly happy, equal ending, leaving the others behind.

However, the organisers' analyses also identified processes and practices that challenged the notion of secularism as a condition for both democracy and gender equality and thus also the binarity and construction of the white European modern secular we. This in-stabilisation was caused by the numerous interventions into the women's and the workers' movement and the presumed truth of the gender-equality norm. It was done through the owners' takeover of the streets and squares. The interventions revealed the acts of exclusion in colonialism and nationalism committed not only by states but also by political movements. Without these exclusions, neither gender equality nor the modernist women's and the workers' movements would be the same.

Not only the state and the EU were interpellated by the placards, speeches and march itself. Not the least, the women addressed themselves as subjects. They were not just the others, the excluded ones, the passive. Through mobilisations and postcolonial education, they talked to themselves, as in Jaja's speech, as historical subjects. They talked to themselves as those who made interventions into societal conditions, those who should call through megaphones, those who should take their place in the streets and the squares. Rights, however liberal they might have 
sounded, were not only for other women, for whites, for Christians. The imagination of Swedish gender equality, in all its uncertainty, was also an object to demand the right to enter and develop. However, that was not enough. They also pointed to a possible transformation and critique of civilisation asserting that religion in general and Islam in particular should not be treated as hostile to gender equality or individual rights.

Here, it is possible to trace their strategy. The march showed the importance of continuing to be a political we, not looking like the privileged, being a visual group through the veil, connected to and followed by allies who had neither the possibility nor the ambition to dissolve, assimilate or integrate them. The owners of the march, therefore, did not understand the privileged positions as desired or given or their own as essential. The existence of more than one linear path to gender equality undermines the narrative of colonial modernity and Swedish white exceptionalism. The owners and the organisers for the march were struggling for another modernity and less predictable future for both themselves and the privileged.

\section{Notes}

1. My special thanks and gratitude to Maimuna Abdullahi. Without your generosity and analyses this chapter had not been possible.

2. I use the concept 'veil' in the critical tradition of Fanon (1965), Scott (2007) and Abu-Lughod (2013).

3. The groups Revolutionary Hijabis and Voice of Hijabis organised similar marches in Malmoe and Stockholm.

4. Maimuna Abdullhai Bältespännarpaken, speech.

5. Motstånd är vårt hopp/Rätten till våran kropp/Jobb är vår rättighet/Och tillsammans skapas solidaritet.

\section{References}

Abu-Lughod, Lila. 2013. Do Muslim women need saving? Cambridge, MA: Harvard University Press.

Ahmed, Sara. 2004. The cultural politics of emotion. Edinburgh: Edinburgh University Press. 
Amer, Sahar. 2014. What is veiling. Chapel Hill: University of North Carolina Press.

Anderson, Benedict. 2016. Imagined communities: Reflections on the origin and spread of nationalism. London: Verso.

Antirasistiska Akademin. 2019. http://www.antirasistiskaakademin.se/ sabrin-jaja-emma-domingues-antirasistiska-rorelsers-kamp-for-demokrati/ Anzaldúa, Gloria. 1999. Borderlands: The new mestiza $=$ La Frontera. 2 nd ed. San Francisco: Aunt Lute Books.

Asad, Talal. 2009. Free speech, blasphemy and secular criticism. In Is critique secular? ed. Talal Asad, Judith Butler, Wendy Brown, and Saba Mahmood, 20-64. Berkeley: University of California Press.

Berg, Linda, Mikela Lundahl, and Lena Martinsson. 2016. Sekulariteter: Förstahet genom religion och kön [Secularities: The first through religion and gender]. Kvinder, Køn og Forskning 25 (4): 7-19.

Butler, Judith. 1990. Gender Trouble. New York: Routledge.

Butler, Judith. 2015. Notes toward a performative theory of assembly. Cambridge, MA: Harvard University Press.

Çağatay, Selin. 2018. Women's coalitions beyond the laicism-Islamism divide in Turkey: Towards an inclusive struggle for gender equality? Social Inclusion 6 (4): 48-58.

Court of Justice of the European Union. 2017. Judgements in Case C-157/15. press release No 30/17. Luxembourg.

De los Reyes, Paulina. 2016. When feminism became gender equality and antiracism turned into diversity management. In Challenging the myth of gender equality in Sweden, ed. Lena Martinsson, Gabriel Griffin, and Katarina Giritli Nygren, 23-47. Bristol: Policy Press.

Edelman, Lee. 2004. No future: Queer theory and the death drive. Durham: Duke University Press.

Fanon, Frantz. 1963. The wretched of the earth. New York: Grove Press. Grove Press.

Farris, Sara R. 2017. In the name of women's rights: The rise of femonationalism. Durham: Duke University Press.

Giritli Nygren, Katarina, Lena Martinsson, and Diana Mulinari. 2018. Gender equality and beyond: At the crossroads of neoliberalism, anti-gender movements, 'European' values, and normative reiterations in the Nordic model. Social Inclusion 6 (4): 1-7.

Halberstam, Judith. 2005. In a queer time and place: Transgender bodies, subcultural lives. New York: New York University Press. 
Kundnani, Arun. 2015. The Muslims are coming!: Islamophobia, extremism, and the domestic war on terror. London: Verso.

Laclau, Ernesto, and Chantal Mouffe. 1985. Hegemony \& socialist strategy. London: Verso.

Larsson, Berit. 2010. Ett delat rum [A shared room]. Gothenburg: Makadam.

Lilja, Mona, and Lena Martinsson. 2018. Travelling artefacts. Journal of Resistance 4 (2): 84-111.

Mahmood, Saba. 2009. Religious reasons and secular affect: An incommensurable divide? In Is critique secular? ed. Talal Asad, Judith Butler, Wendy Brown, and Saba Mahmood, 64-101. Berkeley: University of California Press.

Martinson, Mattias. 2017. Sekularism, populism, xenofobi. [Secularism, populism, xenophobia] Malmö: Eskaton.

Martinsson, Lena, and Eva Reimers. 2016. Political subjectivity and the experiment of democracy: A conclusion. In Education and political subjectivities in neoliberal times and places: Emergences of norms and possibilities, ed. Lena Martinsson and Eva Reimers, 130-134. London: Routledge.

Martinsson, Lena, Gabriele Griffin, and Katarina Giritli Nygren, eds. 2016. Challenging the myth of gender equality in Sweden. Bristol: Policy Press.

Mohanty, Chandra Talpade. 2003. Feminism without borders: Decolonizing theory, practicing solidarity. Durham: Duke University Press.

Mouffe, Chantal. 2013. Hegemony and new political subjects: Towards a new concept of democracy. In Chantal Mouffe. Hegemony, radical democracy, and the political, ed. James Martin. London: Routledge.

- 2018. For a left populism. London: Verso.

Puar, Jasbir K. 2007. Terrorist assemblages: Homonationalism in queer times. Durham: Duke University Press.

Rivera Cusicanqui, Silvia. 2012. Ch'ixinakax utxiwa: A reflection on the practices and discourses of decolonization. The South Atlantic Quarterly 111 (1): 95-109.

Scott, Joan Wallach. 2007. The politics of the veil. Princeton: Princeton University Press.

2018. Sex and secularism. Princeton: Princeton University Press.

Spivak, Gayatri Chakravorty. 1993. Outside in the teaching machine. London: Routledge. 
Lena Martinsson is Professor in Gender Studies at the University of Gothenburg, Sweden. Her main research interests are political subjectivity, social movements and transnationalism in the field of feminist, queer and decolonial studies. Her recent publications include: Challenging the myth of gender equality in Sweden (Martinsson et al. 2016); Dreaming global change, doing local feminisms (Martinsson and Mulinari 2018); Education and political subjectivities in neoliberal times and places: Emergences of norms and possibilities (Reimers and Martinsson 2017).

Open Access This chapter is licensed under the terms of the Creative Commons Attribution 4.0 International License (http://creativecommons.org/licenses/ by/4.0/), which permits use, sharing, adaptation, distribution and reproduction in any medium or format, as long as you give appropriate credit to the original author(s) and the source, provide a link to the Creative Commons licence and indicate if changes were made.

The images or other third party material in this chapter are included in the chapter's Creative Commons licence, unless indicated otherwise in a credit line to the material. If material is not included in the chapter's Creative Commons licence and your intended use is not permitted by statutory regulation or exceeds the permitted use, you will need to obtain permission directly from the copyright holder.

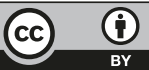

